\title{
The ID01 selective inhibitor epacadostat enhances dendritic cell immunogenicity and lytic ability of tumor antigen-specific $\mathrm{T}$ cells
}

\author{
Caroline Jochems ${ }^{1}$, Massimo Fantini ${ }^{1}$, Romaine I. Fernando ${ }^{1}$, Anna R. Kwilas ${ }^{1}$, \\ Renee N. Donahue ${ }^{1}$, Lauren M. Lepone ${ }^{1}$, Italia Grenga ${ }^{1}$, Young-Seung Kim ${ }^{2}$, Martin \\ W. Brechbiel' ${ }^{2}$, James L. Gulley ${ }^{3}$, Ravi A. Madan ${ }^{3}$, Christopher R. Heery ${ }^{1}$, James W. \\ Hodge $^{1}$, Robert Newton ${ }^{4}$, Jeffrey Schlom ${ }^{1, *}$, Kwong Y. Tsang ${ }^{1, *}$ \\ ${ }^{1}$ Laboratory of Tumor Immunology and Biology, Center for Cancer Research, National Cancer Institute, National Institutes \\ of Health, Bethesda, MD, USA \\ ${ }^{2}$ Radioimmune Inorganic Chemistry Section, Radiation Oncology Branch, Center for Cancer Research, National Cancer \\ Institute, National Institutes of Health, Bethesda, MD, USA \\ ${ }^{3}$ Genitourinary Malignancies Branch, Center for Cancer Research, National Cancer Institute, National Institutes of Health, \\ Bethesda, MD, USA \\ ${ }^{4}$ Incyte Corporation, Wilmington, DE, USA \\ "These authors contributed equally to this work
}

Correspondence to: Jeffrey Schlom, email: js141c@nih.gov

Keywords: IDO inhibitor, dendritic cells, T cells, indoleamine-2,3-dioxygenase (IDO), Tregs

Received: February 29, 2016

Accepted: April 26, 2016

Published: May 12, 2016

\section{ABSTRACT}

Epacadostat is a novel inhibitor of indoleamine-2,3-dioxygenase-1 (IDO1) that suppresses systemic tryptophan catabolism and is currently being evaluated in ongoing clinical trials. We investigated the effects of epacadostat on (a) human dendritic cells (DCs) with respect to maturation and ability to activate human tumor antigen-specific cytotoxic T-cell (CTL) lines, and subsequent T-cell lysis of tumor cells, (b) human regulatory $\mathrm{T}$ cells (Tregs), and (c) human peripheral blood mononuclear cells (PBMCs) in vitro. Simultaneous treatment with epacadostat and IFN-Y plus lipopolysaccharide (LPS) did not change the phenotype of matured human DCs, and as expected decreased the tryptophan breakdown and kynurenine production. Peptidespecific T-cell lines stimulated with DCs pulsed with peptide produced significantly more IFN-Y, TNFa, GM-CSF and IL-8 if the DCs were treated with epacadostat. These $T$ cells also displayed higher levels of tumor cell lysis on a per cell basis. Epacadostat also significantly decreased Treg proliferation induced by IDO production from IFN-Y plus LPS matured human DCs, although the Treg phenotype did not change. Multicolor flow cytometry was performed on human PBMCs treated with epacadostat; analysis of 123 discrete immune cell subsets revealed no changes in major immune cell types, an increase in activated $\mathrm{CD} 83^{+}$conventional $\mathrm{DCs}$, and a decrease in immature activated $\mathrm{Tim}^{+} \mathrm{NK}^{+}$cells. These studies show for the first time several effects of epacadostat on human DCs, and subsequent effects on CTL and Tregs, and provide a rationale as to how epacadostat could potentially increase the efficacy of immunotherapeutics, including cancer vaccines.

\section{INTRODUCTION}

Indoleamine-2,3-dioxygenase-1 (IDO1) is an intracellular immunoregulatory enzyme that contributes to immunosuppression, tolerance and tumor escape by catabolizing tryptophan. It is the first and ratelimiting step in tryptophan (Trp) degradation, leading to subsequent production of kynurenines (Kyn). Studies in human in vitro systems have shown that depletion of tryptophan leads to an immunosuppressive tumor environment through (a) amino acid starvation of $\mathrm{T}$ cells, which leads to inhibition of T-cell proliferation [1-3], and (b) accumulation of Trp metabolites such as Kyn and kynurenic acid, which bind to the cytoplasmic transcription factor aryl hydrocarbon receptor (AhR) [4], leading to differentiation of naïve $\mathrm{CD}^{+} \mathrm{T}$ cells 
into regulatory $\mathrm{T}$ cells (Tregs) and suppression of $\mathrm{T}_{\mathrm{H}} 17$ cells [5-7], as well as promotion of a tolerogenic dendritic cell (DC) phenotype through action on IDO ${ }^{\mathrm{NEG}}$ DCs [3]. AhR also induces IDO-production by human DCs in a feedback loop that further inhibits T-cell proliferation [3]. The role of AhR on $\mathrm{CD}^{+} \mathrm{T}$ cells is not yet known. The role of AhR in controlling disease tolerance and generation of Tregs has also been studied in mice $[4,8]$. Expression of functional IDO enzyme has been demonstrated in multiple human tumors of various origin [9], in DCs [10], macrophages [2], and in plasmacytoid DCs in tumor-draining lymph nodes [11]. IDO-expression has been associated with decreased immune cell infiltration and an increased infiltration of Tregs in tumors [12]. A high expression of IDO has been associated with increased frequencies of metastasis in patients with colorectal carcinoma [13], hepatocellular carcinoma [14], and endometrial tumors [15], and with invasive uterine cervical cancer [16]. IDO-expression also increases as melanoma progresses [17] and has been identified as an independent prognostic marker of survival in several cancers. Low IDO-expression correlated with longer overall survival in patients with hepatocellular carcinoma [14], endometrial cancer [15], and non-small-cell lung cancer [18]. In addition, IDO has been identified as a critical resistance mechanism in antitumor immunotherapy targeting the immune checkpoint CTLA-4 [19].

Inhibition of IDO is a very promising area of cancer immunotherapy, and three drugs that are currently in clinical trials are 1-methyl-tryptophan (1-MT), NLG919, and epacadostat. 1-MT was first described as an IDO inhibitor in 1991 [20], and is now being tested in clinical trials as 1-methyl-D-tryptophan (indoximod and NLG8189). Oral indoximod has been well tolerated alone or in combination with docetaxel, and there have been some objective responses [21, 22]. Epacadostat is an orally active hydroxyamidine small molecule inhibitor, which selectively inhibits the enzymatic activity of IDO1, with little or no activity against IDO2 and TDO (tryptophan-2,3-dioxygenase) [23, 24]. It competitively blocks Trp binding to IDO1 and its subsequent degradation to Kyn, thus increasing Trp levels and decreasing the accumulation of metabolites. Ex vivo lipopolysaccharide (LPS) plus IFN- $\gamma$ stimulation of whole blood samples from patients enrolled on a phase I trial in advanced cancers recently showed that $>90 \%$ inhibition of IDO1 could be achieved in a dose-dependent manner, and it was well tolerated with grade 1-2 fatigue as the most common adverse event [25, 26].

In the studies reported here the use of IFN- $\gamma$ in combination with LPS for IDO induction in DCs was used to maximize the IDO activity from DCs to investigate the effects of the epacadostat inhibitor. The studies reported here were conducted in vitro to investigate the effects of epacadostat on (a) human DCs with respect to maturation and antigen presentation as determined by phenotypic analysis, (b) activation of tumor antigen-specific cytotoxic $\mathrm{T}$ cells (CTL), and their subsequent lysis of tumor cells, (c) Treg proliferation and function, and (d) treatment of human peripheral blood mononuclear cells (PBMCs) and analysis of 123 discrete immune cell subsets.

\section{RESULTS}

\section{Maturation of human DCs with IFN- $\gamma$ plus LPS resulted in the highest levels of IDO1 mRNA and IDO intracellular expression}

Human DCs for all experiments were generated from healthy donors as described in Materials and Methods, and used for subsequent experiments after maturation. We first wanted to evaluate the most effective way to mature the DCs to induce maximum production of IDO1. DCs were subjected to flow cytometry either immature or after maturation with CD40L (24 hours), IFN- $\gamma(50 \mathrm{ng} / \mathrm{ml})$ or IFN- $\gamma(50 \mathrm{ng} / \mathrm{ml})$ plus LPS $(1 \mu \mathrm{g} /$ ml) (48 hours). As seen in Table 1, maturation with IFN- $\gamma$ or IFN- $\gamma$ plus LPS increased the expression of IDO1 by intracellular staining compared to both immature cells and cells matured with CD40L. Maturation with IFN- $\gamma$ plus LPS also resulted in the highest levels of the DC activation markers CD80 and CD83. Thus for all further studies, DCs were matured with the combination of IFN- $\gamma$ and LPS to induce maximal IDO1-production. To confirm the increased expression of IDO1 in IFN- $\gamma$ plus LPS matured DCs, the human PrimeFlow ${ }^{\mathrm{TM}}$ RNA Assay was used to detect IDO1 mRNA transcripts. As can be seen in Figure 1 , maturation with CD40L, IFN- $\gamma$, or IFN- $\gamma$ plus LPS resulted in IDO1 mRNA transcripts in $7.3 \%, 26.8 \%$ and $32.7 \%$ of DCs, respectively.

Studies were undertaken to determine if epacadostat changed the expression levels of activation markers on matured human DCs. DCs were prepared from two different healthy donors. After 5 days, the DCs were matured by the addition of IFN- $\gamma$ plus LPS for 48 hours to induce IDO1 expression, and various concentrations of epacadostat were added simultaneously. Our initial studies showed that epacadostat could more efficiently inhibit IDO1-production when added concurrently with IFN- $\gamma$ and LPS, and that incubation for 48 hours was preferable to 24 hours. After 48 hours, cells were detached and subjected to phenotypic analysis by flow cytometry. There were no significant changes in the expression levels of CD80, CD83, programmed cell death protein-1 (PD-1), programmed cell death protein-1 ligand (PD-L1), or B7-DC (PD-L2) between cells treated with various concentrations of epacadostat (Table 2A). The presence of active IDO1 enzyme can be measured by evaluation of the levels of Trp and the levels of its metabolite Kyn, as well as the Kyn/Trp ratio, by HPLC. Trp and Kyn were measured in the supernatants of immature DCs and DCs 
Table 1: Maturation of human dendritic cells with IFN- $\gamma$ plus LPS resulted in higher levels of intracellular IDO1 expression

\begin{tabular}{|l|c|c|c|}
\hline \multicolumn{1}{r}{ Dendritic cells } & $\begin{array}{c}\text { IDO1 }^{+} \\
\text {(\%) }\end{array}$ & $\begin{array}{c}\text { CD80 }^{+} \\
\text {(\%) }\end{array}$ & $\begin{array}{c}\text { CD83 }^{+} \\
\text {(\%) }^{+}\end{array}$ \\
\hline Immature & 8.0 & 19.9 & 37.0 \\
\hline CD40L & 8.3 & 48.3 & 73.9 \\
\hline IFN- $\gamma$ IFN- $\gamma$ plus LPS & 26.8 & 52.6 & 71.1 \\
\hline
\end{tabular}

Human DCs were generated from a healthy donor. Immature DCs and DCs matured with CD40L (24 hours), IFN- $\gamma$ (48 hours), or IFN- $\gamma$ plus LPS (48 hours) were analyzed for the expression of IDO1, CD80 and CD83 by flow cytometry. Results are expressed as \% positive cells of all CD11 $\mathrm{c}^{+}$DCs in 1 out of 3 donors assayed.

matured with IFN- $\gamma$ or IFN- $\gamma$ plus LPS, treated with or without epacadostat. As seen in Table 2B, the Trp level (expressed as the percent of the original amount of Trp that remains) was $75.8 \%$ in supernatants of immature DCs with little breakdown to Kyn $(24.2 \%)$ and a Kyn/Trp ratio of 0.32 . In contrast, in supernatants of matured DCs without the inhibitor, there was appreciable breakdown of Trp, with a Kyn/Trp ratio of 5.9 for the DCs matured with IFN- $\gamma$, and 9.2 for DCs matured with IFN- $\gamma$ plus LPS. Treatment with $1 \mu \mathrm{M}$ of epacadostat resulted in almost no breakdown of Trp, and Kyn levels as low as 3.3\% and $0 \%$, respectively.

\section{Effect on antigen-specific $T$ cells after stimulation with peptide-pulsed DCs treated with epacadostat}

A CEA-specific T-cell line derived from a cancer patient was stimulated as previously described [27] using CEA-peptide pulsed DCs exposed to $0,0.25$ or $1.0 \mu \mathrm{M}$ of epacadostat. As seen in Table 3A, T-cell stimulation with peptide-pulsed DCs treated with epacadostat resulted in significantly higher levels of IFN- $\gamma$ in supernatants, as compared to those not treated with the IDO-inhibitor. Additional cytokines were measured in a similar experiment using a $\mathrm{C}$-terminus of mucin-1 (MUC1-C)-specific T-cell line; after treating the DCs with 0 or $1.0 \mu \mathrm{M}$ of epacadostat before peptide-pulsing them, levels of IFN- $\gamma$, GM-CSF, IL- 8 , and TNF $\alpha$ were found to have increased (Table 3B). These data thus demonstrated that treating DCs with the IDO-inhibitor epacadostat increased their capacity to stimulate $\mathrm{CD} 8^{+}$antigen-specific T-cell lines in vitro.

A MUC1-C-specific HLA-A24 ${ }^{+}$T-cell line derived from a patient with prostate cancer was stimulated using its specific MUC1 peptide and DCs treated with $0,0.25$ or $1.0 \mu \mathrm{M}$ of epacadostat. Five days after stimulation, the T cells were used in a CTL assay using PC3 (human prostate carcinoma, $\mathrm{MUC1}^{+}$, HLA-A24 $4^{+}$as a target and ASPC-1 (human pancreatic carcinoma, $\mathrm{MUC1}^{+}, \mathrm{HLA}-\mathrm{A} 24^{\mathrm{NEG}}$ ) as a negative control. Pre-treating the DCs with epacadostat resulted in increased tumor cell lysis (Table 3C).
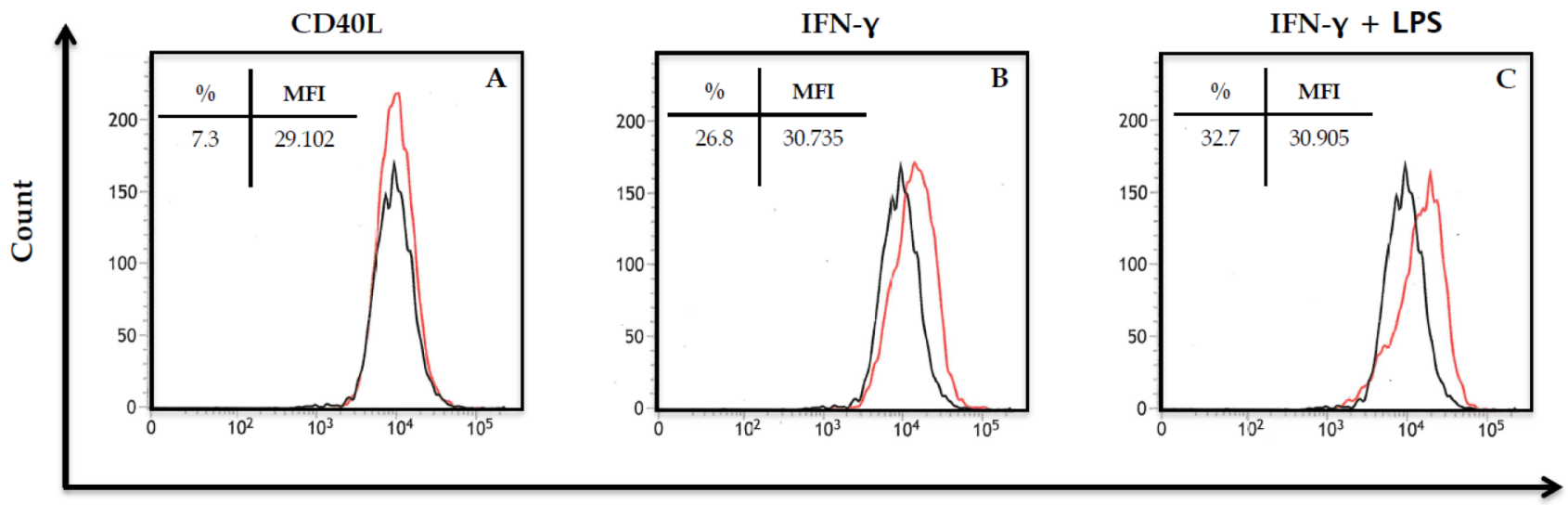

IDO1 mRNA transcripts

Figure 1: Detection of IDO1 mRNA transcripts in mature dendritic cells. Dendritic cells were generated from a healthy donor, and matured with CD40L $(1 \mu \mathrm{g} / \mathrm{ml})$ for 24 hours (A), IFN- $\gamma(50 \mathrm{ng} / \mathrm{ml})$ for 48 hours $(\mathbf{B})$, or IFN- $\gamma(50 \mathrm{ng} / \mathrm{ml}) \mathrm{plus} \mathrm{LPS}(1 \mu \mathrm{g} / \mathrm{ml})$ for 48 hours (C). IDO1 mRNA transcripts were detected using the human PrimeFlow ${ }^{\mathrm{TM}}$ RNA assay. Results are expressed as percent IDO1 $\mathrm{mRNA}^{+}$cells in the CD11 $\mathrm{c}^{+}$population (red) compared to immature dendritic cells (black: 6.9\%). The experiment was repeated in 3 additional donors with similar results. 
Table 2A: Treatment with epacadostat did not change the expression levels of CD80, CD83, PDL1, PD-1, or B7-DC (PD-L2) on IFN- $\gamma$ plus LPS matured human DCs

\begin{tabular}{|c|c|c|c|c|c|c|}
\hline HD & $\begin{array}{c}\text { Epacadostat } \\
(\mu \mathrm{M})\end{array}$ & $\mathrm{CD80}^{+}$ & $\begin{array}{l}\mathrm{CD80}^{+} \\
\mathrm{CD83}^{+}\end{array}$ & $\begin{array}{l}\mathrm{CD80}^{+} \\
\text {PD-L1 }^{+}\end{array}$ & $\begin{array}{l}\text { CD80 }^{+} \\
\text {PD-1 }^{+}\end{array}$ & $\begin{array}{l}\mathrm{CD80}^{+} \\
{\mathrm{B} 7-\mathrm{DC}^{+}}^{+}\end{array}$ \\
\hline$\# 1$ & 0 & 90.3 & 64.0 & 90.3 & 0.09 & 34.9 \\
\hline$\# 1$ & 0.05 & 91.6 & 67.3 & 91.6 & 0 & 33.5 \\
\hline$\# 1$ & 0.25 & 93.9 & 72.2 & 93.9 & 0.09 & 30.1 \\
\hline$\# 1$ & 1.0 & 92.6 & 69.8 & 92.6 & 0 & 30.0 \\
\hline$\# 2$ & 0 & 92.5 & 71.8 & 92.5 & 0 & 32.0 \\
\hline$\# 2$ & 0.05 & 94.7 & 77.8 & 94.7 & 0 & 31.3 \\
\hline$\# 2$ & 0.25 & 95.0 & 78.7 & 95.0 & 0 & 31.0 \\
\hline$\# 2$ & 1.0 & 94.5 & 77.0 & 94.5 & 0 & 31.9 \\
\hline
\end{tabular}

Table 2B: Treatment with epacadostat decreased the breakdown of tryptophan by matured human DCs
DCs
IFN- $\gamma$

plus LPS

\begin{tabular}{|c|c|c|c|c|c|}
\hline Immature & - & - & 24.2 & 75.8 & 0.32 \\
\hline Mature & IFN- $\gamma$ & 0 & 85.5 & 14.8 & 5.9 \\
\hline Mature & IFN- $\gamma$ & $1.0 \mu \mathrm{M}$ & 3.3 & 96.7 & 0.03 \\
\hline Mature & IFN- $\gamma$ plus LPS & 0 & 90.2 & 9.8 & 9.2 \\
\hline Mature & IFN- $\gamma$ plus LPS & $1.0 \mu \mathrm{M}$ & 0 & 100 & - \\
\hline
\end{tabular}

A. Human DCs were generated from 2 healthy donors (HD \#1 and \#2). PBMCs were plated for 2 hours at $2 \times 10^{7} \mathrm{PBMCs} /$ well in a 6-well plate in AIM-V medium. After careful washing, the adherent monocytes were cultured for 5 days in AIM-V medium containing rhGM-CSF $(100 \mathrm{ng} / \mathrm{ml})$ and rhIL-4 $(20 \mathrm{ng} / \mathrm{ml})$. Immature DCs were then treated for 48 hours with IFN- $\gamma(50 \mathrm{ng} / \mathrm{ml})$ and LPS $(1 \mu \mathrm{g} / \mathrm{ml})$ with or without epacadostat at different concentrations. After trypsinization and careful scraping, DCs were subjected to flow cytometry. Results are expressed as \% positive cells of all DCs. B. The concentrations of tryptophan (Trp) and kynurenine (Kyn) were evaluated by HPLC in 48 hours in supernatants of immature DCs or DCs matured with IFN- $\gamma$ or IFN- $\gamma$ plus LPS, and treated with or without epacadostat for 48 hours. Results are expressed as the $\%$ of the original amount of Trp that has been catabolized (Kyn) or that remains (Trp), and as the Kyn/Trp ratio.

An additional HLA-A2-restricted T-cell line, specific for brachyury peptide, was derived from another prostate cancer patient; after stimulation with epacadostat $(1 \mu \mathrm{M})$ - treated DCs, the lysis of the human breast cancer cell line MDA-MB231 increased from $3.5 \%$ to $26.9 \%$ (Table 3C). These results thus demonstrated for the first time that epacadostat treatment of DCs prior to peptidepulsing resulted in both increased cytokine production and increased tumor cell lysis by antigen-specific $\mathrm{CD} 8^{+} \mathrm{T}$-cell lines derived from cancer patients.

\section{Effect of epacadostat on PBMC immune cell subsets}

Human PBMCs from 10 healthy donors were analyzed by multiparameter flow cytometry after 48 hours incubation with epacadostat $(0,0.25$ or $1.0 \mu \mathrm{M})$. A total of 123 peripheral immune cell subsets were examined for changes following treatment (see Supplementary Table 1). These included nine standard parental immune cell types $\left(\mathrm{CD} 4^{+}\right.$and $\mathrm{CD} 8^{+} \mathrm{T}$ cells, Tregs, B cells, natural killer (NK) cells, NKT cells, conventional dendritic cells (cDCs), plasmacytoid DCs (pDCs), and myeloid derived suppressor cells (MDSCs)), and 114 subsets of these cell types relating to maturation and function. All of the nine standard immune cell types were unchanged following epacadostat treatment (Table 4). Of the 114 subsets relating to maturation and function, only two were changed following treatment with $1 \mu \mathrm{M}$ of epacadostat. There was a significant increase (from 0.009 to $0.011 \%$ of PBMCs, $P=0.02$ ) in cDCs expressing CD83, a marker of activation, with seven out of 10 donors having a greater than $25 \%$ increase. There was also a significant decrease (from 0.007 to $0.004 \%$ of PBMCs, $P=0.02$ ) in immature NK cells expressing T-cell immunoglobulin and mucin domain-3 (Tim-3) $)^{+}$a marker of activation, with seven out of 10 donors having a greater than $25 \%$ decrease. However, as the frequencies of these subsets are low as a percent of total PBMCs, these changes are considered to be only notable trends. Thus, treatment of PBMCs with 
Table 3A and 3B: Peptide-specific T cells produced increased levels of IFN- $\gamma$ after stimulation with peptide-pulsed DCs exposed to epacadostat

A

\begin{tabular}{|l|c|c|c|c|}
\hline \multirow{2}{*}{\multicolumn{2}{c}{ CEA peptide }} & \multicolumn{3}{c}{ Epacadostat } \\
\cline { 3 - 5 } \multicolumn{1}{c|}{} & & $\mathbf{0} \boldsymbol{\mu M}$ & $\mathbf{0 . 2 5} \boldsymbol{\mu M}$ & $\mathbf{1 . 0} \boldsymbol{\mu M}$ \\
\hline DCs $+\mathrm{T}$ cells & - & $<15.6$ & $<15.6$ & $<15.6$ \\
\hline DCs + T cells & + & $\mathbf{2 9 1}$ & $\mathbf{6 0 2}$ & $\mathbf{2 , 7 5 0}$ \\
\hline DCs & - & $<15.6$ & NA & $<15.6$ \\
\hline DCs & + & $<15.6$ & NA & $<15.6$ \\
\hline
\end{tabular}

B

\begin{tabular}{|l|c|c|c|c|c|}
\hline \multicolumn{2}{c}{ Epacadostat } & IFN- $\boldsymbol{\gamma}$ & GM-CSF & IL-8 & TNF $\boldsymbol{\alpha}$ \\
\hline $\mathrm{DCs}+\mathrm{T}$ cells & 0 & 42 & 124 & 29 & 7.5 \\
\hline $\mathrm{DCs}+\mathrm{T}$ cells & $1.0 \mu \mathrm{M}$ & 669 & 1,745 & 412 & 191 \\
\hline
\end{tabular}

Table 3C: Lysis of human tumor cells increased after peptide-specific T-cell lines were stimulated with peptide-pulsed DCs exposed to epacadostat

\begin{tabular}{|c|c|c|c|c|c|}
\hline T-cell line & $\begin{array}{c}\text { DC: } T \text { cell } \\
\text { ratio }\end{array}$ & $\begin{array}{c}\text { Epacadostat } \\
\mu \mathrm{M}\end{array}$ & $\begin{array}{c}\text { PC3 } \\
\text { \% lysis (SD) }\end{array}$ & $\begin{array}{c}\text { MDA-MB231 } \\
\text { \% lysis (SD) }\end{array}$ & $\begin{array}{c}\text { ASPC-1 } \\
\% \text { lysis (SD) }\end{array}$ \\
\hline \multirow[t]{3}{*}{ MUC1-C } & $1: 5$ & 0 & $41.0(4.5)$ & - & 0 \\
\hline & & 0.25 & $58.1(4.3)^{*}$ & - & $2.0(1.1)$ \\
\hline & & 1.0 & $56.7(7.5)^{*}$ & - & $1.8(0.1)$ \\
\hline \multirow[t]{3}{*}{ MUC1-C } & $1: 1$ & 0 & $54.8(4.4)$ & - & $1.3(0.1)$ \\
\hline & & 0.25 & $69.6(3.4)^{*}$ & - & $2.4(0.3)$ \\
\hline & & 1.0 & $64.6(3.9)^{*}$ & - & $1.5(0.5)$ \\
\hline \multirow[t]{2}{*}{ Brachyury } & $1: 5$ & 0 & - & $3.5(0.6)$ & $0.2(0.2)$ \\
\hline & & 1.0 & - & $26.9(1.6)^{*}$ & $6.1(1.6)$ \\
\hline
\end{tabular}

A. A CEA-specific T-cell line was stimulated using CEA peptide and DCs exposed to $0,0.25$ or $1.0 \mu \mathrm{M}$ of epacadostat as previously described [27]. Stimulation with DCs exposed to epacadostat resulted in significantly higher levels of IFN- $\gamma$ in supernatants after 24 hours. NA: not available. B. A MUC1-C-specific T-cell line produced significantly higher levels of cytokines after 24 hours stimulation with peptide-pulsed DCs exposed to epacadostat. C. A MUC1-C-specific, HLA-A24 T-cell line derived from a patient with prostate cancer was stimulated using its specific MUC1-C peptide and DCs exposed to $0,0.25$ or $1.0 \mu \mathrm{M}$ of epacadostat. Five days after stimulation, the T cells were used in a CTL assay using PC3 (human prostate carcinoma, $\mathrm{MUC1}^{+}, \mathrm{HLA}-\mathrm{A} 24^{+}$) as a target and ASPC-1 (human pancreatic carcinoma, MUC1 $1^{+}$, HLA-A24 $4^{\mathrm{NEG}}$ ) as a negative control. Results are expressed as $\%$ lysis (SD) at an effector:target ratio of 30:1. A brachyury-specific, HLA-A2 ${ }^{+}$ T-cell line derived from another patient with prostate cancer was stimulated using its specific peptide and DCs exposed to 0 , or $1.0 \mu \mathrm{M}$ of epacadostat and used in a CTL assay using MDA-MB231 (human breast carcinoma, brachyury ${ }^{+}$, HLA-A2 ${ }^{+}$) as a target and ASPC- 1 as a negative control. Results are expressed as \% lysis (SD) at an effector:target ratio of $60: 1 .{ }^{*} P<0.05$ by paired $t$-test compared to no treatment. The experiments have been repeated multiple times, and the table shows one of them.

epacadostat resulted in little or no change in the phenotype of any of 123 immune cell subsets in the absence of any additional stimulation.

\section{Effect of epacadostat on Tregs}

Dendritic cells were generated from two healthy donors, matured with IFN- $\gamma$ plus LPS with or without epacadostat, and then used for co-culture with autologous isolated $\mathrm{CD}^{+} \mathrm{T}$ cells for 5 days, after which flow cytometry was performed. As seen in Table 5A, there were no significant differences in the expression levels of FoxP3, CTLA-4 or CCR4 on Tregs (defined as CD4 $\mathrm{CD} 25^{+}, \mathrm{CD} 127^{\mathrm{NEG}}, \mathrm{FoxP}^{+}$) after 5 days in culture with DCs exposed to epacadostat $(1.0 \mu \mathrm{M})$ or DCs treated only with IFN- $\gamma$ plus LPS (Table 5A).

A proliferation assay of similarly treated Tregs or $\mathrm{CD}^{+} \mathrm{T}$ cells with antigen-presenting cells (APCs) from freshly thawed PBMCs from the same donor was performed. As can be seen in Table 5B, maturation of DCs 
Table 4: Standard immune cell types in healthy donors following 48 hours treatment with epacadostat

\begin{tabular}{l|c|c|c|c|}
\multicolumn{1}{c}{$\begin{array}{c}\text { Immune } \\
\text { cell type }\end{array}$} & $\begin{array}{c}\text { Epacadostat } \\
\mathbf{0}\end{array}$ & \multicolumn{1}{c}{$\begin{array}{c}\text { Epacadostat } \\
\mathbf{0 . 2 5} \boldsymbol{\mu M}\end{array}$} & $\begin{array}{c}\text { Epacadostat } \\
\mathbf{1} \boldsymbol{\mu M}\end{array}$ & \multicolumn{2}{c}{$\boldsymbol{P}$-value } \\
\hline $\mathrm{CD}^{+}$ & 38 & 38 & 26 & 0.85 \\
\hline $\mathrm{CD}^{+}$ & 27 & 27 & 0.9 & 0.56 \\
\hline Tregs & 1.2 & 1.2 & 11 & 0.28 \\
\hline B cells & 10 & 10 & 1.6 & 0.69 \\
\hline NK & 1.7 & 1.6 & 0.7 & 0.08 \\
\hline NKT & 0.7 & 0.7 & 0.16 & 0.43 \\
\hline cDC & 0.16 & 0.17 & 0.004 & 0.37 \\
\hline pDC & 0.004 & 0.005 & 0.5 & 0.77 \\
\hline MDSC & 0.6 & 0.5 & 0.32 \\
\hline
\end{tabular}

Human PBMCs from 10 healthy donors were subjected to multiparameter flow cytometric evaluation after 48 hours incubation with epacadostat $(0,0.25$ or $1.0 \mu \mathrm{M})$. Nine standard immune cell types were analyzed. Values are displayed as the median frequency of PBMCs. There were no significant changes between the treatment groups (Wilcoxon matched-pairs signed rank test).

cDC, conventional dendritic cells; MDSC, myeloid derived suppressor cells; NK, natural killer; NKT, natural killer T cells; PBMCs, peripheral blood mononuclear cells; pDC, plasmacytoid DC; Tregs, regulatory T cells.

with IFN- $\gamma$ plus LPS without the IDO-inhibitor resulted in four times more Tregs per plate compared to maturation with CD40L. The number of Tregs decreased when epacadostat was added. The proliferation rate as measured by counts per minute (CPM) also increased for Tregs after maturation with IFN- $\gamma$ plus LPS, and decreased upon treatment with epacadostat. Taken together, these results demonstrated that epacadostat decreased Treg proliferation without altering the Treg phenotype.

\section{DISCUSSION}

The IDO1 enzyme inhibitor epacadostat represents a new class of inhibitor, a hydroxyamidine small molecule, which potently inhibits IDO1 function without affecting IDO2 and TDO. It has been very well tolerated in clinical trials. It was evaluated in a phase I dose escalation study (NCT01195311), and led to stable disease for more than 8 weeks in $30 \%$ of the 52 enrolled patients with refractory disease. The trial did not reach dose-limiting toxicity, and the recommended monotherapy dose is $600 \mathrm{mg}$ twice daily. Preliminary results from a phase I/II combination therapy trial with epacadostat and ipilimumab in melanoma patients showed $6 / 8$ patients with tumor reduction by the first evaluation [28]. There are currently 13 ongoing trials with epacadostat alone or in combination therapy in ovarian, fallopian tube, and primary peritoneal cancer, melanoma, non-small cell lung cancer, myelodysplastic syndromes and advanced solid tumors. Preclinically, combination therapy with epacadostat and anti-CTLA-4 or anti-PD-1/PD-L1 improved tumor control and increased IL-2 production and CD8 T-cell proliferation in murine melanoma better than single agent therapy [29]. The finding of cytotoxic $\mathrm{T}$ cells specific for IDO1 in both healthy individuals and cancer patients provides further evidence for the immunogenicity of IDO1 [30]. These cells are capable of lysing tumor cells and DCs expressing IDO1, which boosts the immune response [30, 31]. A clinical trial evaluating a vaccine containing a peptide derived from IDO was recently completed in patients with metastatic malignant melanoma (NCT02077114). Common approaches for evaluation of IDO activity include (a) IDO1 protein expression by Western blot, immunohistochemistry and/or flow cytometry, (b) IDO1 mRNA expression, and (c) determination of Trp consumption and Kyn accumulation; this determination of Trp consumption and Kyn accumulation by HPLC is indispensible. We have analyzed IDO activity employing all three approaches to investigate the ability of the IDO1 inhibitor epacadostat to reverse the functional activity of the IDO1 enzyme.

Epacadostat has been shown to increase the survival of human DCs and decrease DC apoptosis, and to enhance $\mathrm{CD}^{+}$and $\mathrm{CD} 8^{+} \mathrm{T}$-cell proliferation and IFN $\gamma$ production, which could potentially result in more efficient priming of T cells [24]. We therefore wanted to evaluate its effects on DC stimulation of tumor associated antigen-specific cytotoxic T-cell lines in vitro. As expected, epacadostat treatment of DCs decreased the breakdown of Trp and accumulation of Kyn in supernatants. We found no phenotypic changes in the epacadostat-treated matured DCs by flow cytometry. We show for the first time that pre-treating human DCs with epacadostat before they were used to stimulate peptide-specific T-cell lines derived 
Table 5A: Phenotypic analysis of regulatory $T$ cells from healthy donors after co-culture with autologous DCs matured with IFN- $\gamma$ plus LPS and treated with epacadostat

\begin{tabular}{|l|c|c|c|c|c|}
\hline \multicolumn{1}{c}{ Donor } & $\begin{array}{c}\text { Epacadostat } \\
\boldsymbol{\mu M}\end{array}$ & $\begin{array}{c}\text { \% CTLA-4 } \\
\text { Tregs }\end{array}$ & $\begin{array}{c}\text { FoxP3 } \\
\text { MFI }\end{array}$ & \% CCR4 ${ }^{+}$/ CD4 & $\begin{array}{c}\text { CCR4 } \\
\text { MFI }\end{array}$ \\
\hline$\# \mathbf{1}$ & 0 & 7.7 & 1,576 & 9.3 & 11,126 \\
\hline & 1.0 & 9.2 & 1,553 & 8.1 & 10,498 \\
\hline $\mathbf{2}$ & 0 & 3.6 & 1,449 & 12.5 & 8,404 \\
\hline & 1.0 & 3.3 & 1,349 & 11.8 & 7,945 \\
\hline
\end{tabular}

Table 5B: IDO-producing human DCs induce proliferation of Tregs, which can be inhibited by epacadostat

\begin{tabular}{|l|c|c|c|c|c|}
\hline \multicolumn{1}{r}{ Maturation } & \multicolumn{1}{c}{$\begin{array}{c}\text { Epacadostat } \\
\boldsymbol{\mu M}\end{array}$} & $\begin{array}{c}\text { Tregs } \\
\text { Cell count }\end{array}$ & $\begin{array}{c}\text { Tregs } \\
\text { CPM }\end{array}$ & $\begin{array}{c}\text { CD4 T cells } \\
\text { CPM }\end{array}$ & $\begin{array}{c}\text { APCs } \\
\text { CPM }\end{array}$ \\
\hline CD40L & 0 & $1.2 \times 10^{5}$ & 5,564 & 15,566 & 1,317 \\
\hline IFN- $\gamma$ plus LPS & 0 & $4.9 \times 10^{5}$ & 46,290 & 23,411 & 778 \\
\hline IFN- $\gamma$ plus LPS & 0.25 & $3.3 \times 10^{5}$ & 21,308 & 15,353 & 675 \\
\hline IFN- $\gamma$ plus LPS & 1.0 & $2.6 \times 10^{5}$ & 22,631 & 23,385 & 834 \\
\hline
\end{tabular}

A. DCs were generated from 2 healthy donors, matured with IFN- $\gamma$ plus LPS with or without epacadostat, and then used for co-culture with autologous purified $\mathrm{CD} 4^{+} \mathrm{T}$ cells for 5 days. Flow cytometry was performed after 5 days. Tregs were defined as $\mathrm{CD}^{+}, \mathrm{CD} 25^{+}, \mathrm{CD} 127^{\mathrm{NEG}}$, and FoxP3 ${ }^{+}$cells. Results are shown as frequency and MFI. B. Dendritic cells were generated from a healthy donor and matured with IFN- $\gamma$ plus LPS to induce IDO production as described in Materials and Methods. $\mathrm{CD}^{+} \mathrm{T}$ cells were isolated from the same donor and added to the culture at $2 \times 10^{6} /$ well in 6 wells each with $0,0.25$ or $1.0 \mu \mathrm{M}$ of epacadostat. Five days later, Tregs were isolated from the cultures and counted, and a proliferation assay using these Tregs with autologous purified $\mathrm{CD}^{+} \mathrm{T}$ cells and irradiated APCs from freshly thawed PBMCs was performed. Results are shown as the cell count for Tregs (isolated $\mathrm{CD} 4^{+}, \mathrm{CD} 25^{+}, \mathrm{CD} 127^{\mathrm{NEG}}$ ) after the first proliferation of a total of $12 \times 10^{6} \mathrm{CD} 4^{+} \mathrm{T}$ cells, as well as the counts per minute from the proliferation of Tregs $\left(10^{4} / \mathrm{well}\right), \mathrm{CD} 4^{+} \mathrm{T}$ cells $\left(\mathrm{CD} 4^{+}, \mathrm{CD} 25^{\mathrm{NEG}}\right)\left(10^{4} / \mathrm{well}\right)$, and APCs (irradiated PBMCs left over after isolation of T cells) $\left(10^{5} /\right.$ well). Results shown are from 1 healthy donor out of several assayed.

from cancer patients resulted in increased production of IFN- $\gamma$ and increased lysis of human tumor cell line targets expressing various tumor-associated antigens.

It has previously been shown in the P815 murine tumor model that potentially immunogenic tumor cells that express IDO1 are protected from immune-mediated rejection, and that treatment with the IDO-inhibitor 1-MT can revert this effect [9]. Ito et al. previously found that the induction of $\mathrm{HBsAg}$-specific CTL in mice after vaccination was upregulated by IDO inhibition using 1-MT [32]. The increase in tumor cell lysis observed in the study reported here after CTL stimulation with epacadostat-treated DCs, and the potentially increased immunogenicity of tumor cells observed after IDO-inhibitor treatment, thus provide a rationale for combination therapy of epacadostat with cancer vaccines able to induce T-cell anti-tumor activity. It has also been demonstrated that IDO1 expression and activity can lead to the generation of reactive oxygen species (ROS) in various cell types in both humans and mice $[33,34]$. Treatment of NK cells with Kyn can induce growth inhibition and apoptosis of human NK cells, and inhibit anti-tumor activity of NK cells against IDO positive cancer cells. Kyn-induced NK-cell apoptosis in humans is primarily through an ROS-mediated pathway
$[35,36]$. In addition, it has been suggested that ROS can inhibit anti-cancer activity of $\mathrm{T}$ cells and lead to cell death of cytotoxic T cells $[37,38]$. The IDO1 inhibitor epacadostat can interact with NK cells as well as CTLs and IDO1-producing tumor cells in regulating the immune responses.

IDO1-expression is associated with increased differentiation of naïve CD4 $\mathrm{T}$ cells into Tregs in humans [5-7], and with increased infiltration of Tregs in tumor [12]. We show here that Treg proliferation was increased in the presence of IDO1, and treatment with epacadostat decreased the Treg proliferation. There were no phenotypic changes to Tregs after treatment. It has further been suggested that one mechanism by which IDO can enhance Treg activity is by inhibiting Tregs from undergoing phenotypic reprogramming. Reprogramming in the $\mathrm{CD}^{+}$lineage refers to the alteration of the mature and differentiated $\mathrm{CD} 4^{+}$subsets to acquire phenotypic and functional characteristics of other subsets [39]. IDO1 can block Treg reprogramming at least in part by inhibition of IL-6 production [40]. IL-6 is an important cytokine driving the abrogation of functional Treg suppressive activity in vivo [41], and reprogramming of Tregs into IL17 -producing $\mathrm{T}_{\mathrm{H}} 17$ cells in vitro [42]. 
In a recent review of IDO pathway inhibitors [43], the authors conclude that IDO-inhibition has been well tolerated in cancer patients, with clinical anticancer effects seen in a subset of patients, and that combination therapy with chemotherapy, radiotherapy or immunotherapy may be effective against a wide range of malignancies. The immune enhancing data reported here support the combination of epacadostat with such therapies. The combined decrease in Treg proliferation and increase in CTL activity seen with IDO1 inhibition supplies the rationale for clinical studies employing the combination of epacadostat and cancer vaccines or other immunotherapeutics. We also demonstrate for the first time that in vitro treatment of human PBMCs with epacadostat did not change any peripheral immune cell subsets in a way that could have a negative biological impact on concurrent vaccine therapy. In future studies, it would be interesting to investigate different cancer types and stages for the ability of epacadostat to enhance dendritic cell immunogenicity and the lytic ability of antigen-specific T cells.

\section{MATERIALS AND METHODS}

\section{Generation of dendritic cells from PBMCs}

Peripheral blood was collected from healthy volunteer donors from the National Institutes of Health Clinical Center Blood Bank (Bethesda, MD, USA) (NCT00001846), and PBMCs were isolated by centrifugation on a density gradient (Lymphocyte Separation Medium, ICN Biochemicals, Aurora, VA). DCs were generated using a modification of the previously described procedure [44]. DCs were cultured in AIM-V medium containing $100 \mathrm{ng} / \mathrm{ml}$ GM-CSF and $20 \mathrm{ng} / \mathrm{ml} \mathrm{IL-4}$ (PeproTech, Rocky Hill, NJ). After 5 days in culture, the DCs were matured by the addition of $1 \mu \mathrm{g} / \mathrm{ml} \mathrm{CD} 40 \mathrm{~L}$ and $1 \mu \mathrm{g} / \mathrm{ml}$ enhancer (Enzo Life Sciences, Farmingdale, NY) for 24 hours as a control, IFN- $\gamma(50 \mathrm{ng} / \mathrm{ml})$ for 48 hours, or IFN- $\gamma(50 \mathrm{ng} / \mathrm{ml})$ and LPS $(1 \mu \mathrm{g} / \mathrm{ml})$ for 48 hours to induce IDO1 expression. The combination of LPS and IFN- $\gamma$ led to the highest IDO1 expression, and was chosen for most experiments, since our aim was to evaluate the effects of the IDO-inhibitor epacadostat on the different immune cells, and not to mimic the clinical situation.

\section{IDO-inhibitor}

The IDO1 selective inhibitor epacadostat, obtained through a Cooperative Research and Development Agreement with Incyte Corporation (Wilmington, $\mathrm{DE}$ ), was dissolved in DMSO and used at different concentrations as described. The concentration used in most experiments, $1.0 \mu \mathrm{M}$, was chosen to mimic the serum concentration observed in patients receiving 300 mg BID, where there was $>90 \%$ inhibition of IDO1 [25].
When the dose was increased further in patients there was no additional effect, and at lower doses the efficacy was decreased in a dose proportional manner.

\section{Tumor cell cultures}

The human pancreatic carcinoma cell line ASPC-1 $\left(\mathrm{HLA}_{-} 1^{+}, \mathrm{HLA}-\mathrm{A} 26^{+}, \mathrm{MUC1}^{+}\right)$, prostate cancer cell line PC3 (HLA-A24 ${ }^{+}, \mathrm{MUC1}^{+}$), and breast cancer cell line MDA-MB231 (HLA-A2 ${ }^{+}$, brachyury ${ }^{+}$) were purchased from American Type Culture Collection (Manassas, VA). All cell cultures were free of mycoplasma and maintained in complete medium (RPMI 1640 supplemented with $10 \%$ fetal calf serum, $100 \mathrm{U} / \mathrm{ml}$ penicillin, $100 \mu \mathrm{g} / \mathrm{ml}$ streptomycin and $2 \mathrm{mM}$ L-glutamine; Mediatech, Herndon, VA).

\section{T-cell lines and CTL assays}

MUC1-, CEA- and brachyury-specific HLA-A2and HLA-A24-restricted T-cell lines were established and used for evaluation of IFN- $\gamma$ production and in indium-111 release CTL assays as previously described [27]. For the experiments using MUC1-C-specific T-cell lines and DCs, we utilized PBMCs from two prostate cancer patients enrolled in a previously described clinical trial of PSA-TRICOM vaccine in combination with ipilimumab [45]. The CEA-specific T-cell line was derived from a patient with metastatic carcinoma treated with a recombinant CEA-vaccinia vaccine in a phase I trial [46]. In all experiments with antigen-specific T-cell lines, the DCs were derived from HLA-matched healthy donors. An Institutional Review Board of the National Institutes of Health (NIH) Clinical Center had approved the procedures, and informed consent was obtained in accordance with the Declaration of Helsinki.

\section{Detection of cytokines}

Autologous DCs matured with IFN- $\gamma$ plus LPS for 48 hours were pulsed with peptides and incubated with CEA- or MUC1-specific T-cell lines for 24 hours. The supernatants were then analyzed for IFN- $\gamma$ by ELISA (Invitrogen, Frederick, MD), or by Multi-Array technology (Meso Scale Diagnostics, Gaithersburg, MD) for detection of additional cytokines.

\section{Flow cytometric analysis}

For flow analysis, $5 \times 10^{5}$ cells were stained in $100 \mu \mathrm{l}$ staining buffer (PBS, 1\% BSA) for 30 minutes at $4^{\circ} \mathrm{C}$. Events were acquired on an LSRII flow cytometer (BD Bioscience, San Jose, CA) and analysis was performed in FlowJo 9.5.2 (Treestar Inc., Ashland, OR). Antibodies used for flow cytometric analysis were: CD80-FITC (BD), CD83-BV421 (BioLegend, San Diego, CA), 
HLA-DR-V500 (BD), CD11c-PECy7 (BD), CD11cBV605 (BioLegend), PD-L1-FITC (clone M1H1, BD), B7-DC (PD-L2)-PerCPEFluor710 (eBioscience, San Diego, CA) and IDO-PE (clone 700838) (R\&D Systems, Minneapolis, MN).

\section{Detection of IDO1 mRNA}

The expression of IDO1 mRNA was evaluated by the human PrimeFlow ${ }^{\mathrm{TM}}$ RNA assay (eBioscience) per the manufacturer's instructions. Briefly, after surface staining of mature or immature DCs using CD11c-PE-Cy7 (BD) and CD83-BV421 (BioLegend), cells were permeabilized, and then hybridized with the type 4 Human RPL13A Alexa Fluor ${ }^{\circledR} 488$ (Affymetrix, cat. VA4-13187) and the type 1 IDO 1 Human Alexa Fluor ${ }^{\circledR} 647$ (Affymetrix, cat. VA1-14451) probes, per the protocol instructions. After hybridization, cells were acquired using the BD FACSVerse $^{\mathrm{TM}}$ flow cytometer (BD). Analysis to detect IDO mRNA transcripts was performed using the BD FACSuite $^{\mathrm{TM}}$ software (BD).

\section{High-performance liquid chromatography (HPLC)}

All samples were analyzed by reverse-phase HPLC using a Beckman system Gold HPLC (Fullerton, CA) equipped with a 126 solvent module and $168 \mathrm{UV}$ detector $(\lambda=254 \mathrm{~nm})$ controlled by 32 Karat software and Beckman Ultrasphere column (ODS, $4.6 \times 250 \mathrm{~mm}$, $5 \mu \mathrm{m})$. The flow rate was $1 \mathrm{ml} / \mathrm{min}$ and the mobile phase was isocratic with $90 \% \mathrm{~A} \mathrm{(1} \mathrm{mM} \mathrm{phosphate} \mathrm{buffer,} \mathrm{pH} 4)$ and $10 \% \mathrm{~B}$ (methanol) for 20 minutes.

\section{In vitro epacadostat treatment of healthy donor PBMCs}

PBMCs from 10 healthy volunteers were obtained from the NIH Clinical Center Blood Bank (NCT00001846), incubated overnight and then treated with $0,0.25$ or $1.0 \mu \mathrm{M}$ of epacadostat for 48 hours before flow cytometric analysis of 123 distinct immune cell subsets (Supplemental Table 1) using a panel of 30 different markers (Supplemental Table 2) as previously described [47].

\section{ACKNOWLEDGMENTS}

The authors thank Debra Weingarten for her editorial assistance in the in the preparation of this manuscript.

\section{CONFLICTS OF INTEREST}

The authors declare no conflicts of interest.

\section{GRANT SUPPORT}

This research was supported by the Intramural Research Program of the Center for Cancer Research, National Cancer Institute, National Institutes of Health, as well as through a Cooperative Research and Development Agreement (CRADA) between the National Cancer Institute and Incyte Corporation.

\section{REFERENCES}

1. Mellor AL, Munn DH. Tryptophan catabolism and T-cell tolerance: immunosuppression by starvation? Immunol Today. 1999; 20:469-473.

2. Munn DH, Shafizadeh E, Attwood JT, Bondarev I, Pashine A, Mellor AL. Inhibition of T cell proliferation by macrophage tryptophan catabolism. J Exp Med. 1999; 189:1363-1372.

3. Hwu P, Du MX, Lapointe R, Do M, Taylor MW, Young HA. Indoleamine 2,3-dioxygenase production by human dendritic cells results in the inhibition of $\mathrm{T}$ cell proliferation. J Immunol. 2000; 164:3596-3599.

4. Bessede A, Gargaro M, Pallotta MT, Matino D, Servillo G, Brunacci C, Bicciato S, Mazza EM, Macchiarulo A, Vacca C, Iannitti R, Tissi L, Volpi C, et al. Aryl hydrocarbon receptor control of a disease tolerance defence pathway. Nature. 2014; 511:184-190.

5. Curti A, Pandolfi S, Valzasina B, Aluigi M, Isidori A, Ferri E, Salvestrini V, Bonanno G, Rutella S, Durelli I, Horenstein AL, Fiore F, Massaia M, et al. Modulation of tryptophan catabolism by human leukemic cells results in the conversion of CD25- into CD25+ T regulatory cells. Blood. 2007; 109:2871-2877.

6. Chen W, Liang X, Peterson AJ, Munn DH, Blazar BR. The indoleamine 2,3-dioxygenase pathway is essential for human plasmacytoid dendritic cell-induced adaptive T regulatory cell generation. J Immunol. 2008; 181:53965404.

7. Chung DJ, Rossi M, Romano E, Ghith J, Yuan J, Munn DH, Young JW. Indoleamine 2,3-dioxygenase-expressing mature human monocyte-derived dendritic cells expand potent autologous regulatory T cells. Blood. 2009; 114:555-563.

8. Mezrich JD, Fechner JH, Zhang X, Johnson BP, Burlingham WJ, Bradfield CA. An interaction between kynurenine and the aryl hydrocarbon receptor can generate regulatory T cells. J Immunol. 2010; 185:3190-3198.

9. Uyttenhove C, Pilotte L, Theate I, Stroobant V, Colau D, Parmentier N, Boon T, Van den Eynde BJ. Evidence for a tumoral immune resistance mechanism based on tryptophan degradation by indoleamine 2,3-dioxygenase. Nat Med. 2003; 9:1269-1274.

10. Munn DH, Sharma MD, Lee JR, Jhaver KG, Johnson TS, Keskin DB, Marshall B, Chandler P, Antonia SJ, 
Burgess R, Slingluff CL Jr, Mellor AL. Potential regulatory function of human dendritic cells expressing indoleamine 2,3-dioxygenase. Science. 2002; 297:1867-1870.

11. Munn DH, Sharma MD, Hou D, Baban B, Lee JR, Antonia SJ, Messina JL, Chandler P, Koni PA, Mellor AL. Expression of indoleamine 2,3-dioxygenase by plasmacytoid dendritic cells in tumor-draining lymph nodes. J Clin Invest. 2004; 114:280-290.

12. Munn DH. Indoleamine 2,3-dioxygenase, Tregs and cancer. Curr Med Chem. 2011; 18:2240-2246.

13. Brandacher G, Perathoner A, Ladurner R, Schneeberger S, Obrist P, Winkler C, Werner ER, Werner-Felmayer G, Weiss HG, Gobel G, Margreiter R, Konigsrainer A, Fuchs D, et al. Prognostic value of indoleamine 2,3-dioxygenase expression in colorectal cancer: effect on tumor-infiltrating T cells. Clin Cancer Res. 2006; 12: 1144-1151.

14. Pan K, Wang H, Chen MS, Zhang HK, Weng DS, Zhou J, Huang W, Li JJ, Song HF, Xia JC. Expression and prognosis role of indoleamine 2,3-dioxygenase in hepatocellular carcinoma. J Cancer Res Clin Oncol. 2008; 134:1247-1253.

15. Ino K, Yamamoto E, Shibata K, Kajiyama H, Yoshida N, Terauchi M, Nawa A, Nagasaka T, Takikawa O, Kikkawa F. Inverse correlation between tumoral indoleamine 2,3-dioxygenase expression and tumor-infiltrating lymphocytes in endometrial cancer: its association with disease progression and survival. Clin Cancer Res. 2008; 14:2310-2317.

16. Nakamura T, Shima T, Saeki A, Hidaka T, Nakashima A, Takikawa O, Saito S. Expression of indoleamine 2, 3-dioxygenase and the recruitment of Foxp3-expressing regulatory $\mathrm{T}$ cells in the development and progression of uterine cervical cancer. Cancer Sci. 2007; 98:874-881.

17. Polak ME, Borthwick NJ, Gabriel FG, Johnson P, Higgins B, Hurren J, McCormick D, Jager MJ, Cree IA. Mechanisms of local immunosuppression in cutaneous melanoma. Br J Cancer. 2007; 96:1879-1887.

18. Astigiano S, Morandi B, Costa R, Mastracci L, D'Agostino A, Ratto GB, Melioli G, Frumento G. Eosinophil granulocytes account for indoleamine 2,3-dioxygenase-mediated immune escape in human nonsmall cell lung cancer. Neoplasia. 2005; 7:390-396.

19. Holmgaard RB, Zamarin D, Munn DH, Wolchok JD, Allison JP. Indoleamine 2,3-dioxygenase is a critical resistance mechanism in antitumor $\mathrm{T}$ cell immunotherapy targeting CTLA-4. J Exp Med. 2013; 210:1389-1402.

20. Cady SG, Sono M. 1-Methyl-DL-tryptophan, beta(3-benzofuranyl)-DL-alanine (the oxygen analog of tryptophan), and beta-[3-benzo(b)thienyl]-DL-alanine (the sulfur analog of tryptophan) are competitive inhibitors for indoleamine 2,3-dioxygenase. Arch Biochem Biophys. 1991; 291:326-333.

21. Jackson E, Dees EC, Kauh JS, Harvey RD, Neuger A, Lush R, Antonia SJ, Minton SE, Ismail-Khan R, Han HS, Vahanian NN, Ramsey WJ, Link CJ, et al. A phase I study of indoximod in combination with docetaxel in metastatic solid tumors. 2013 ASCO Annual Meeting. J Clin Oncol. 2013; 31 (suppl; abstr 3026).

22. Soliman H, Antonia S, Sullivan D, Vanahanian N, Link CJ. Overcoming tumor antigen anergy in human malignancies using the novel indeolamine 2,3-dioxygenase (IDO) enzyme inhibitor, 1-methyl-D-tryptophan (1MT). 2009 ASCO Annual Meeting J Clin Oncol. 2009; 27 (suppl; abstr 3004).

23. Koblish HK, Hansbury MJ, Bowman KJ, Yang G, Neilan CL, Haley PJ, Burn TC, Waeltz P, Sparks RB, Yue EW, Combs AP, Scherle PA, Vaddi K, et al. Hydroxyamidine inhibitors of indoleamine-2,3-dioxygenase potently suppress systemic tryptophan catabolism and the growth of IDO-expressing tumors. Mol Cancer Ther. 2010; 9:489-498.

24. Liu X, Shin N, Koblish HK, Yang G, Wang Q, Wang K, Leffet L, Hansbury MJ, Thomas B, Rupar M, Waeltz P, Bowman KJ, Polam P, et al. Selective inhibition of IDO1 effectively regulates mediators of antitumor immunity. Blood. 2010; 115:3520-3530.

25. Beatty GL, O'Dwyer PJ, Clark J, Shi JG, Newton RC, Schaub R, Maleski J, Leopold L, Gajewski T. Phase I study of the safety, pharmacokinetics (PK), and pharmacodynamics (PD) of the oral inhibitor of indoleamine 2,3-dioxygenase (IDO1) INCB024360 in patients (pts) with advanced malignancies. 2013 ASCO Annual Meeting. J Clin Oncol. 2013; 31 (suppl; abstr 3025).

26. Newton RC, Scherle PA, Bowman K, Liu X, Beatty GL, O’Dwyer PJ, Gajewski T, Bowman J, Schaub R, Leopold L. Pharmacodynamic assessment of INCB024360, an inhibitor of indoleamine 2,3-dioxygenase 1 (IDO1), in advanced cancer patients. 2012 ASCO Annual Meeting. J Clin Oncol. 2012; 2012 (suppl;abstr 2500).

27. Jochems C, Tucker JA, Vergati M, Boyerinas B, Gulley JL, Schlom J, Tsang KY. Identification and characterization of agonist epitopes of the MUC1-C oncoprotein. Cancer Immunol Immunother. 2014; 63:161-174.

28. Gibney GT, Hamid O, Gangadhar TC, Lutzky J, Olszanski AJ, Gajewski T, Chmielowski B, Boasberg PD, Zhao Y, Newton RC, Scherle PA, Bowman J, Maleski J, et al. Preliminary results from a phase $1 / 2$ study of INCB024360 combined with ipilimumab (ipi) in patients (pts) with melanoma. 2014 ASCO Annual Meeting. J Clin Oncol. 2014; 32 (suppl; abstr 3010).

29. Spranger S, Koblish HK, Horton B, Scherle PA, Newton R, Gajewski TF. Mechanism of tumor rejection with doublets of CTLA-4, PD-1/PD-L1, or IDO blockade involves restored IL-2 production and proliferation of CD8 $(+) \mathrm{T}$ cells directly within the tumor microenvironment. J Immunother Cancer. 2014; 2:3.

30. Sorensen RB, Berge-Hansen L, Junker N, Hansen CA, Hadrup SR, Schumacher TN, Svane IM, Becker JC, thor Straten P, Andersen MH. The immune system strikes back: cellular immune responses against indoleamine 2,3-dioxygenase. PLoS One. 2009; 4:e6910. 
31. Sorensen RB, Hadrup SR, Svane IM, Hjortso MC, Thor Straten P, Andersen MH. Indoleamine 2,3-dioxygenase specific, cytotoxic $\mathrm{T}$ cells as immune regulators. Blood. 2011; 117:2200-2210.

32. Ito H, Ando T, Ando K, Ishikawa T, Saito K, Moriwaki H, Seishima M. Induction of hepatitis B virus surface antigenspecific cytotoxic $\mathrm{T}$ lymphocytes can be up-regulated by the inhibition of indoleamine 2,3-dioxygenase activity. Immunology. 2014; 142:614-623.

33. Cetindere T, Nambiar S, Santourlidis S, Essmann F, Hassan M. Induction of indoleamine 2,3-dioxygenase by death receptor activation contributes to apoptosis of melanoma cells via mitochondrial damage-dependent ROS accumulation. Cell Signal. 2010; 22:197-211.

34. Ogasawara N, Oguro $T$, Sakabe T, Matsushima M, Takikawa O, Isobe K, Nagase F. Hemoglobin induces the expression of indoleamine 2,3-dioxygenase in dendritic cells through the activation of PI3K, PKC, and NF-kappaB and the generation of reactive oxygen species. J Cell Biochem. 2009; 108:716-725.

35. Hansson M, Asea A, Ersson U, Hermodsson S, Hellstrand K. Induction of apoptosis in NK cells by monocyte-derived reactive oxygen metabolites. J Immunol. 1996; 156:42-47.

36. Song H, Park H, Kim YS, Kim KD, Lee HK, Cho DH, Yang JW, Hur DY. L-kynurenine-induced apoptosis in human NK cells is mediated by reactive oxygen species. Int Immunopharmacol. 2011; 11:932-938.

37. Betten A, Dahlgren C, Mellqvist UH, Hermodsson S, Hellstrand K. Oxygen radical-induced natural killer cell dysfunction: role of myeloperoxidase and regulation by serotonin. J Leukoc Biol. 2004; 75:1111-1115.

38. Hellstrand K. Melanoma immunotherapy: a battle against radicals? Trends Immunol. 2003; 24:232-233; author reply 234.

39. Jasperson LK, Bucher C, Panoskaltsis-Mortari A, Taylor PA, Mellor AL, Munn DH, Blazar BR. Indoleamine 2,3-dioxygenase is a critical regulator of acute graft-versushost disease lethality. Blood. 2008; 111:3257-3265.
40. Baban B, Chandler PR, Sharma MD, Pihkala J, Koni PA, Munn DH, Mellor AL. IDO activates regulatory T cells and blocks their conversion into Th17-like T cells. J Immunol. 2009; 183:2475-2483.

41. Pasare C, Medzhitov R. Toll pathway-dependent blockade of CD4+CD25+ T cell-mediated suppression by dendritic cells. Science. 2003; 299:1033-1036.

42. Sharma MD, Hou DY, Liu Y, Koni PA, Metz R, Chandler P, Mellor AL, He Y, Munn DH. Indoleamine 2,3-dioxygenase controls conversion of Foxp3+ Tregs to TH17-like cells in tumor-draining lymph nodes. Blood. 2009; 113:6102-6111.

43. Zhai L, Spranger S, Binder DC, Gritsina G, Lauing KL, Giles FJ, Wainwright DA. Molecular pathways: targeting IDO1 and other tryptophan dioxygenases for cancer immunotherapy. Clin Cancer Res. 2015; 21:5427-5433.

44. Tsang KY, Zaremba S, Nieroda CA, Zhu MZ, Hamilton JM, Schlom J. Generation of human cytotoxic T cells specific for human carcinoembryonic antigen epitopes from patients immunized with recombinant vaccinia-CEA vaccine. J Natl Cancer Inst. 1995; 87:982-990.

45. Madan RA, Mohebtash M, Arlen PM, Vergati M, Rauckhorst M, Steinberg SM, Tsang KY, Poole DJ, Parnes HL, Wright JJ, Dahut WL, Schlom J, Gulley JL. Ipilimumab and a poxviral vaccine targeting prostatespecific antigen in metastatic castration-resistant prostate cancer: a phase 1 dose-escalation trial. Lancet Oncol. 2012; 13:501-508.

46. Tsang KY, Zhu M, Nieroda CA, Correale P, Zaremba S, Hamilton JM, Cole D, Lam C, Schlom J. Phenotypic stability of a cytotoxic T-cell line directed against an immunodominant epitope of human carcinoembryonic antigen. Clin Cancer Res. 1997; 3:2439-2449.

47. Lepone LM, Donahue RN, Grenga I, Metenou S, Richards J, Heery CR, Gulley JL, Schlom J. Analyses of 123 peripheral human immune cell subsets: defining differences with age and between healthy donors and cancer patients not detected in analysis of standard immune cell types. J Circ Biomark. 2016; 5. doi: 10.5772/62322. 